\title{
Dymitr ROMANOWSKI
}

Uniwersytet Jagielloński w Krakowie

dymitr.romanowski@uj.edu.pl

\section{CHRZEŚCIJAŃSKI KONSERWATYZM}

\author{
WYBRANE ASPEKTY TEOLOGICZNE W TWÓRCZOŚCI \\ FILARETA MOSKIEWSKIEGO (DROZDOWA)
}

ABSTRACT Christian conservatism. Selected theological aspects in the works of Metropolitan Philaret (Drozdov)

The article aims to present the sources of Russian conservatism, based on the Metropolitan Filaret (Drozdov) works. Special attention is given to the critique of the 'project of the autonomy of reason', which is essential for the political culture of modernity. For Filaret the fundamental paradox of human condition is that the only purpose of human's life is a supernatural goal, or Eternal Life. In the political perspective, it means that it is wrong to accept the existence of a temporal or political order separated from the spiritual order.

Key words: the Church, grace, anthropology, modernity, tradition

Słowa kluczowe: Kościoł, łaska, antropologia, nowoczesność, tradycja 


\section{WSTĘP}

W niniejszym artykule zostanie podjęta próba przedstawienia źródeł rosyjskiego konserwatyzmu na podstawie poglądów metropolity Filareta (Drozdowa). Konserwatyzm jest polemiczną reakcją na Oświecenie, każda jednak „reakcja” oznacza równocześnie konieczność przedstawienia alternatywnej wizji oraz wypracowanie alternatywnej spójnej postawy ideologicznej i politycznej. Należałoby się zastanowić, czy konserwatywna reakcja na Oświecenie jest skierowana wyłącznie przeciwko rewolucyjnym konsekwencjom, które wynikają z „oświeceniowego ideału społecznego”, czy przede wszystkim przeciw samej treści tego ideału, który zakłada tzw. „projekt autonomii rozumu” posługującego się nim indywiduum, co ma podstawowe znaczenie dla politycznej kultury „nowoczesności”. Jak zauważa Joseph Ratzinger, wolność stała się synonimem uwolnienia od normatywnej siły tradycji: człowieka przestała krępować wola i wiedza kogoś innego, drogę woli wskazywało tylko własne rozeznanie. Rozumność jest jednocześnie samookreśleniem, które odrzuca obce określenia narzucane przez autorytet ${ }^{1}$.

Punktem wyjścia filozofii nowożytnej nie jest już świat obiektywny, ale podmiot, który nadaje znaczenie światu. Filozofia nowożytna podkreśla fakt istnienia świata zawsze dla jakiegoś ludzkiego podmiotu, a zbliżanie się do rzeczywistości jest zawsze uwarunkowane przez pytania, które się jej stawia. Kant ułatwił to zbliżenie przez swą metodę transcendentalną. Szukał w podmiocie uwarunkowań określających możliwości poznania. Antropocentryzm Kanta można dostrzec w słynnych pytaniach, które wyznaczały kierunek jego filozofii: co mogę poznawać?, na co mogę mieć nadzieję?²

Wbrew filozofii Oświecenia filozofia konserwatywna uważa, że wszelkie roszczenia do znaczenia nie są zakorzenione w autonomii świadomości ludzkiej, lecz wręcz przeciwnie - w jej heteronomii, czyli w jej zdolności do „wyobrażenia” sobie czegoś innego niż ona sama. Świadomość w takim ujęciu nie jest instancją transcendentalną, która wnosi sens w pierwotnie neutralne istnienie, a jest swego rodzaju „pośrednikiem” objawiającej się rzeczywistości. Takie postawienie problemu przenosi nas w epicentrum polemiki „konserwatyzmu” i „postępowości”, która ostatecznie nie sprowadza się do dylematu „zachowawczości” i „zmiany” czy nawet „tradycji” i „modernizacji”, a do walki o nienaruszalność „zasady rzeczywistości”.

\section{MYŚL TEOLOGICZNA W ROSJI NA PRZEŁOMIE XVIII I XIX W.}

Szczególne miejsce w rosyjskiej myśli religijnej XVII-XVIII w. zajmowała teologia „barokowa”.Chociaż scholastyka czasów nowożytnych zajmowała stanowisko antyreformacyjne

Por. J. Ratzinger, Kościót - znak wśród narodów. Pisma eklezjologiczne i ekumeniczne, cz. 1, przeł. W.Szymona, Lublin 2013, s. 393, Opera Omnia, t. 8/1.

2 Por. J. O’Donnell, Wprowadzenie do teologii dogmatycznej, przeł. J. Szczurek, Kraków 1997, s. 23-24; J. Morales, Wprowadzenie do teologii, przeł. P. Rak, Kraków 2002, s. 172-174. 
i była pojęciowym narzędziem reformy katolickiej, została przejęta przez reformację ortodoksyjną i dlatego zyskała charakter międzykonfesyjny, a wręcz uniwersalny. Karl Eschweiter, który w roku 1928 nadał jej miano „scholastyki barokowej”, zwrócił szczególną uwagę na ten jej uniwersalny charakter. Uznał ją za „ostatni przykład myślenia paneuropejskiego", który przeniknął wszystkie obszary życia duchowego i społecznego ${ }^{3}$.

Barok był swego rodzaju wspólnym zjawiskiem zarówno dla protestantów, jak i katolików czy prawosławnych. W ten sam sposób byty przyjmowane i przejmowane nie tylko poszczególne scholastyczne poglady i opinie, ale sama psychologia i organizacja duchowa. Oczywiście nie byta to „średniowieczna scholastyka”, ale odrodzona scholastyka kontrreformacji jednocześnie "fatszywy klasycyzm" - trydencka scholastyka, teologia Baroku... Światopogląd kijowskich profesorów i studentów w XVII wieku nie byt ograniczony ${ }^{4}$.

W XIX w. pojawiła się „nowa” teologia. Rosyjska teologia XIX-XX w. znajdowała się pod przemożnym wpływem niemieckiej filozofii idealistycznej. Rosyjska myśl zostata obudzona przez niemiecki idealizm - zauważa Florowski - ale nie należy wyolbrzymiać znaczenia tej „recepcji niemieckiego idealizmu” w twórczym powstaniu myśli rosyjskiej. To byto wtaśnie przebudzenie, przebtysk, fascynacja - zachtyśnięcie. [...] Rosyjska dusza zostata wychowana w tym żywiole niemieckiego idealizmu [...] Wakademiach XIX w. rozwinęta sie wtasna tradycja filozoficzna. [...] Problem „Filozofii i Teologii” zostat postawiony dość ostro i otwarcie. Izadanie „usprawiedliwienia wiary ojców” w catościowym religijno-filozoficznym światopogladzie stato przed każdym 5 . Duży wkład w kształtowanie prawosławnego pojęcia Kościoła, najogólniej określanego rosyjskim terminem „soborowość” oznaczającym jednocześnie „katolickość” i „wspólnotę”, wniósł świecki teolog Aleksiej Chomiakow (1804-1860). Ruch słowianofilski rodził się w okresie, kiedy słabły wpływy filozofii francuskiego Oświecenia, panującego ówcześnie, a myśl rosyjska kierowała się w stronę najnowszej filozofii niemieckiej $j^{6}$. Teologia słowianofilów szybko ukształtowała zachodnie wyobrażenie o prawosławiu, mimo iż była bardzo odległa od rzeczywistości historycznej i miała swe źródło w raskole, który wstrząsnął posadami prawosławnej tradycjī.

Oprócz myśli słowianofilskiej, która zdeterminowała podejście badawcze do dziewiętnastowiecznej rosyjskiej myśli religijnej, warto zwrócić uwagę na postać Filareta Moskiewskiego, którego twórczość jest nie mniej ważna dla epoki, choć niezasłużenie pomijana przez badaczy ${ }^{8}$. Metropolita moskiewski Filaret (Drozdow, 1782-1867) opracował podstawy nowego akademickiego wykształcenia teologicznego. Był najbardziej

3 Por. Historia teologii, t. 4: Epoka nowożytna, red. G. Angelini, G. Colombo, M. Vergottin, przeł. W. Szymona, Kraków 2008, s. 233-234.

4 Г. ФАоровский, Пути русского богословия, [online] http://www.predanie.ru, 10 VI 2016; thum. własne - D.R.

5 Tamże.

6 Nie bacząc na krytyczny stosunek do filozofii Hegla takiego myśliciela jak Chomiakow, zdaniem Łosskiego można dopatrzeć się wspólnego źródła, a raczej wspólnego rodowodu filozoficznego myśli rosyjskiej i niemieckiej, zabarwionego niemieckim idealizmem. Por. В. Аосский, По образу и подобию, Москва 1995, [online] http://www.predanie.ru, 10 VI 2016.

7 Por. J. Ratzinger, Kościót - znak..., s. 254.

8 Więcej na ten temat por. D. Romanowski, Źródta rosyjskiej myśli konserwatywnej. Teologia polityczna 
wpływowym i najwybitniejszym przedstawicielem nowej teologii. Zdaniem Gieorgija Fłorowskiego jego największym dziedzictwem pozostają kazania. Filaret nie zbudował całościowego systemu teologicznego, jego spuścizna ma charakter fragmentaryczny, ale te fragmenty cechuje wewnętrzna jedność i całościowość. To coś więcej niż całościowość systemu - to całościowość kontemplacji. Przejawia się w nich żywe teologiczne doświadczenie wynikające z modlitwy i życia kontemplacyjnego. W historii nowożytnej teologii rosyjskiej Filaret Moskiewski był pierwszym, dla którego teologia była zadaniem życiowym, duchowym wysiłkiem. Filaret nie tylko uprawiał teologię on żył Bogiem?.

\section{TEOLOGIA I FILOZOFIA}

Czy można mówić, że w kontekście „zwrotu antropologicznego” współczesnej filozofii teologia Filareta ma również charakter antropocentryczny? Wydaje się, że Filaret uznaje Kantowskie zastrzeżenia dotyczące prostolinijnej metafizyki i próbuje oprzeć się na tym, co umyka krytyce filozofa: od rzeczy odwraca się ku subiektywności, która pragnie rzeczy i je poznaje. Joseph Ratzinger zwrócił uwagę na pewne strukturalne pokrewieństwo - przy niezaprzeczalnych różnicach - Augustyńskiego iluminizmu i Kantowskiego transcendentalizmu. Punkt wyjścia wskazuje na to pewne pokrewieństwo: Augustyn wychodzi od sceptycyzmu późnej Akademii, Kant zaś od sceptycyzmu Davida Hume’a. Sprawia to, że obydwaj są przekonani, iż pewności i ogólnie ważnej konieczności poznania nie da się wyprowadzić z doświadczenia a posteriori. Obydwu zmusza to do uzasadnienia pewności a priori. Jedyna różnica między nimi polega właściwie na tym, że Augustyn zakorzenia ją w świadomości transcendentnej, a Kant - w świadomości transcendentalnej ${ }^{10}$.

Filareta Moskiewskiego, „Politeja” 2016, nr 45, s. 43-62, [online] http://dx.doi.org/10.12797/Politeja.13.2016.45.03.

9 Por. Г. ФАоровский, Пути...

10 Por. J. Ratzinger, Rozumienie objawienia i teologia historii wedtug Bonawentury. Rozprawa habilitacyjna i studia nad Bonawentura, przeł. J. Merecki, Lublin 2014, s. 651, Opera Omnia, t. 2. Warto zwrócić uwagę, że dla Chomiakowa nie ma istotnej różnicy miedzy chrześcijańską filozofią a teologią. Filozofia byłaby zagrożeniem dla teologii tylko w przypadku, gdyby pragnęła zastąpić Prawdę czymś niezgodnym z duchem prawosławia. A tak nie jest - Prawda jest jedna. Można powiedzieć, że słowianofile są przekonani, iż dzięki ich teologii Kościół dopiero zaczyna właściwie rozumieć siebie jako Kościół i Człowieka jako członka Kościoła. Innymi słowy, dzięki ich teologii Kościół uświadamia sobie siebie, dokonuje autentycznego „samo-poznania”. W teologii słowianofilów prawosławie wraca „do siebie”, wyzwala się z zachodniej niewoli, odzyskuje własną godność. Dlatego właśnie filozofia słowianofilów jest Wielką Teologią - ponieważ tylko w tej teologii Kościół ostatecznie zna sam siebie i poznaje siebie jako Kościół. Filozofia w tym ujęciu nie jest już tylko „warunkiem” teologii, nie ma tylko do czynienia z pojęciami, przy pomocy których wyraża się wiara chrześcijańska, a staje się czymś tożsamym z teologią. Jedyna różnica, jaka istnieje między tak rozumianą filozofią a teologią, to fakt, że teolog wnosi w swoje rozważania zaangażowanie wiary - to nie filozofia, lecz żywe życie w Kościele pokazuje prawosławnym, w jaki sposób przejść od egzystencji nieautentycznej do egzystencji autentycznej. Chomiakow punktem wyjścia czyni stanowisko Kanta. Za pomocą działania, które Fichte określa mianem abstrakcji, filozof może pojęciowo wyodrębnić dwa momenty zawsze zjednoczone 
Filaret należy do tego nurtu teologicznego, który podkreśla nieograniczone ludzkie pragnienie poznania; zauważa, że tego pragnienia nie jest w stanie zaspokoić nic na świecie i że może ono przekraczać świat jako całość ${ }^{11}$. Jeśli nawet transcendencja ta jest pustą otchłanią, to jednak nie można zaprzeczyć transcendentalnemu ukierunkowaniu człowieka $^{12}$. Człowiek jest istotą żyjącą, ukierunkowaną na podstawę nie-realistyczną, w której świat empiryczny, do którego sam również należy, znajduje uzasadnienie swego bytu. Czy to my powinniśmy odkrywać wewnętrzne zasady i podstawy przyrody - my, żyjący, jeśli można tak powiedzieć, na jej korze, na jej skorupce? Podstawy takiej nieogarnionej budowli odkryć może tylko Ten, Kto ją stworzyt i odkrywa o tyle, o ile Sam się od$k_{r y w a}{ }^{13}$. Zastanawianie się nad dobrem stanowiącym cel pragnienia wydawało się Filaretowi w rzeczywistości najszybszą drogą dojścia do rozmyślania o Bogu ${ }^{14}$. Podobnie rozum naturalny, chociaż nie w takim gtębokim znaczeniu, może powiedzieć, że prawda jest życiowa strawa ducha ludzkiego. Jeżeli zniszczy się prawde, w umyśle pozostanie jedynie pustka, gtód, pragnienie, tęsknota, męka, jeśli tylko umyst nie jest wodrętwieniu lub omdleniu z powodu skrajnej ignorancji. Jeśli przyjdzie wam do gtowy karmić go obrazami wyobraźni o przemijajacym blasku, ale niezawierajacymi prawdy, szybko znudzi mu się czerpanie wody pozbawionym dna naczyniem, jego pragnienie pozostanie niezaspokojone, a męka nieuleczalna ${ }^{15}$. Innymi słowy, prawdziwemu człowieczeństwu nie odpowiada banalność życia, które sobie po prostu płynie ${ }^{16}$. Filaret dostrzega w ludziach chęć prze-

w realnej świadomości. W ten sposób może sformułować pojęcie inteligencji w sobie (świadomości) i rzeczy w sobie - tak oto otwierają się przed nim dwie drogi. Może spróbować wyjaśnić doświadczenie albo jako pochodzące od inteligencji w sobie, czyli twórczego myślenia, albo jako działanie rzeczy w sobie (konieczność). Pierwsza droga jest oczywiście drogą idealizmu, druga - dogmatyzmu. Por. F. Copleston, Historia filozofii, t. 7: Od Fichtego do Nietzschego, przeł. J. Łoziński, Warszawa 1995, s. 8-17. Dogmatyzm w ostateczności prowadzi do materializmu i determinizmu. Iwan Kiriejewski zauważył, że Spinoza związał rozumowe wnioski o pierwszej przyczynie i porządku świata w całkowitą i nierozerwalną sieć teorematów i sylogizmów. Poprzez tę sieć nie mógł dopatrzeć się w stworzeniu śladów żywego Stwórcy ani dostrzec w człowieku jego wewnętrznej wolności. Myśliciel, którego prawdziwie pociąga wolny przedmiot moralny i który prawdziwie jest nim zainteresowany, kiedy będzie szukać podstawowej zasady filozoficznej, zwróci się ku inteligencji, jaźni czy „ja”, nie zaś ku „nie-ja”. Pośrednictwo Boskiej łaski nie jest tu potrzebne ani wskazane ze względu na zagrożenie możliwą heteronomią. Por. A. Szwed, Rozum wobec chrześcijańskiego Objawienia. Kant, Hegel, Kierkegaard, Kęty 2011, s. 71-77, 80-81, 88- 95. Jak zauważa Ratzinger: Wedtug niego [Fichtego] każdy cztowiek jest autonomicznym duchem, który w catości tworzy siebie samego przez swe postanowienia i jest catkowicie produktem wtasnych decyzji - niczym innym jak tylko wolq i wolnościa, która nie toleruje niczego, co nie jest duchem, i sama nadaje ksztatt swemu wnętrzu. Delikatnie mówiąc, stwórcze ja Fichtego opiera się na pomieszaniu cztowieka z Bogiem... - J. Ratzinger, Teologia liturgii. Sakramentalne podstawy życia chrześcijańskiego, przeł. W. Szymona, Lublin 2012, s. 198, Opera Omnia, t. 11.

11 Por. R. Sokolowski, Bóg wiary i rozumu. Podstawy chrześcijańskiej teologii, przeł. M. Romanek, Kraków 2015, s. 184-185.

12 Por. G.L. Müller, Dogmatyka katolicka, przeł. W. Szymona, Kraków 2015, s. 141.

13 Tu i dalej cyt. za: Фикарет (Ароздов), Творения, [online] http://www.predanie.ru, 10 VI 2016; tłum. własne - D.R.

14 Por. P.P. Gilbert, Wprowadzenie do teologii średniowiecza, przeł. T. Górski, Kraków 1997, s. 82-81.

15 Филарет (Ароздов), Творения.

16 J. Ratzinger, Wrozmowie z czasem, cz. 2, Lublin 2017, s. 840, Opera Omnia, $13 / 2$. 
kroczenia każdego ograniczonego dobra, stan człowieka charakteryzuje pragnienie nieskończoności, aby jednak człowiekowi odsłonił się charakter ostatecznej prawdy, który jest związany z Bogiem, potrzeba spontanicznego samootwarcia się prawdy, którą jest Bóg. Można z pewnością powiedzieć, że każde poznanie Boga opiera się na czynnym i wolnym ukazaniu się Boga. Poznanie Boga nie jest więc sprawą jednostronnie ludzkiej aktywności, lecz implikuje dwie aktywności: człowieka i Boga. Sprawą człowieka jest stopniowe odrzucanie swej własnej fałszywej aktywności i w tej rezygnacji z własnej aktywności otwarcie się na inną, wyższą działalność Boga ${ }^{17}$.

\section{DAR STWORZENIA I DAR ODKUPIENIA}

Kiedy Filaret podejmuje problem doskonalenia i darów łaski, określa je jako coś, co nie pochodzi „ani z natury, ani z zasług”. Już jako stworzenie jesteśmy czystym darem Bożej wolności, gdyż nikt z nas nie może domagać się „prawa” do zaistnienia. Ponadto jesteśmy stworzeni „w” Chrystusie i „przez” Chrystusa; jedynym naszym przeznaczeniem jest uczestnictwo w życiu samego Boga. A więc kontekst stworzenia pozwala rozpatrzyć samo bycie osoby jako dar, a łaska wprowadza w sferę zachowania, w której tego, co należy zrobić, można dokonać jedynie „w” Chrystusie i „przez” Chrystusa. Jakkolwiek liczne i wielkie bytyby dobrodziejstwa Boże dla cztowieka w życiu naturalnym i spotecznym, to przede wszystkim wielkie, wazne, niezliczone i nieopisane sa dobrodziejstwa Boże zwiazane $z$ duchowym i wiecznym życiem cztowieka. Pierwsze dwa rodzaje dobrodziejstw można uznać tylko za przedwstępne i sprzyjające temu ostatniemu. Tam jest darowane stworzeniu bycie, a byciu porzadek, tu grzesznikowi dane jest odpuszczenie grzechów, osadzonemu - przebaczenie, duchowo martwemu - zycie, zaginionemu - zbawienie i szczęście. Tam stworzone zostaje przygotowane i wykorzystane dla dobra stworzonego, tutaj Stwórca Sam przychodzi z pomoca stworzeniu, stuż mu, daje mu Samego Siebie, Syn Boży nie oszczędza się, ale oddaje się za nas wszystkich; ciato i krew Bogocztowieka sa oferowane jako pokarm i napój, jako lekarstwo, jako źródto życia, serce Boże sięotwiera, mitość Boża przelewa się w nasze serca, Duch Święty jest przekazywany, mieszkania wniebie otwieraja się dla ludzi i w sercu cztowieka pojawia się przybytek Boga ${ }^{18}$.

Wszystkie nasze chcenia istnieją tylko w zależności od naszego chcenia pierwotnego, najgłębszego i podstawowego, przez które człowiek chce w sposób absolutny tylko jednej rzeczy, a wszystkich innych dla niej samej. Pewna hierarchia, pewien porządek dóbr czy doskonałości istnieje jednak tylko dzięki temu, że istnieje Dobro absolutne, którego człowiek pragnie w sposób absolutny, nie podporządkowując go żadnemu innemu dobru ${ }^{19}$. Ale jak poprawnie zrozumieć i zdefiniować wolność? Mądrość uczy, że wolność jest zdolnościa rozumnego wyboru tego, co najlepsze, i że z natury jest wtasnościa każ-

17 Por. tenże, Lud i Dom Boży w nauce św. Augustyna o Kościele. Rozprawa doktorska oraz inne opracowania nauki Augustyna i teologii ojców Kościota, przeł. W. Szymona, Lublin 2014, s. 491, Opera Omnia, t. 1.

18 Филарет (Ароздов), Творения.

19 Por. J. Daujat, Łaska i my, przeł. Z. Kowalska, Warszawa 1967, s. 91. 
dego cztowieka. Czegóż, mogtoby się wydawać, chcieć więcej? Ale to wyjaśnienie jest jasne na poziomie rozpatrywania natury ludzkiej, takiej jaka powinna być, a schodzac na poziom doświadczenia i dziatania - jaka jest, natyka się na ciemnotę i przeszkody. Czy wielu, spośród niepoliczonej liczby rodu ludzkiego ma na tyle otwarty $i$ wyksztatcony umyst, aby prawidtowo dostrzec to, co najlepsze? A ci, którzy widza to, co najlepsze, czy zawsze maja dość sity, aby to zdecydowanie wybrać i wprowadzić w czyn? $?^{20}$

Podstawową intencją Filareta jest ukazanie, że wolność stworzona, obdarzona możnością wyboru, realizuje się i staje się rzeczywistą wolnością jedynie w obrębie łaski. W tym kontekście życie w obszarze łaski znaczy, że zostaliśmy uzdolnieni do tego działania, w którym bonum jawi się w pełnym tego słowa znaczeniu jako transcendentalne ${ }^{21}$. Prawdziwa wolność jest aktywna zdolnościa cztowieka, który nie jest w niewoli grzechu, nie jest obciażony osądzającym sumieniem, aby wybrać to, co najlepsze w świetle prawdy Bożej i wprowadzić to w czyn przy pomocy petnej taski mocy Bożej. Przywrócić taka wolność niewolnikowi grzechu może tylko Ten, Kto darowat ja przy stworzeniu bezgrzesznemu człowiekowi ${ }^{22}$. Dar lub łaska pomaga człowiekowi wchodzić w stan autentycznej wolności. Znowu należy tu przypomnieć, że wolność Boża nie może być przeciwstawiana stworzonej jako „inna”, lecz wolność stworzona może się spełnić tylko w wolności absolutnej, która jest tożsama z miłością. Ujmując to w języku Augustyna działanie Boga jest dla człowieka zbyt wewnętrzne, zbyt głęboko w nim, za blisko jego najgłębszej wolności, by mogło znaleźć się wobec niej w jakiejkolwiek relacji przymusu. Bóg bowiem jest bardziej w człowieku niż on $\mathrm{sam}^{23}$.

\section{DWA ŚWIATŁA POZNANIA}

\section{Nauka o oświeceniu}

Jak zostało wyżej powiedziane, człowiek, według Filareta, jest ukierunkowany transcendentalnie, jest ,istotą otwartą poza siebie”. Obdarzony rozumem duch ludzki jest pojmowany przez Filareta jako obraz Boży. Problem obrazu jest ściśle związany z pojęciem poznania. Bycie obrazem Boga w przypadku człowieka polega na tym, że jest on w stanie ująć Boga w poznaniu - obraz jest związany z Bogiem przez relację poznania, dlatego człowiekowi jest również właściwe naturalne dążenie i poznanie tego, na czyj obraz został stworzony. W poznaniu więc dokonuje się powrót stworzenia do jego Stwórcy. Ponieważ cztowiek jest stworzony na obraz Boży, to można z tego wywnioskować,

20 Фикарет (Ароздов), Творения.

21 Ludzkiej wolności nie można ograniczać do samej wolności wyboru między dobrem i złem. Wolność wyboru zakłada zawsze historyczną sytuację woli istniejącej w oddaleniu od Boga. Bardziej pierwotna jest wola rozumiana jako transcendentalna jedność woli z dobrem. Logos realizuje swą zbawczą wolę razem z ludzką wolą i w niej, dlatego tajemnica wcielenia nie umniejsza ludzkiej autonomii, lecz wynosi ją na najwyższy poziom jej stworzonych możliwości. Por. G.L. Müller, Dogmatyka..., s. 380-382.

22 Фикарет (Ароздов), Творения.

23 Por. D. Turner, Tomasz z Akwinu. Portret, przeł. M. Romanek, Warszawa 2017, s. 192. 
że w darze stowa otrzymat cośna obraz twórczego Stowa Bożego. [...] Wewnętrzne światto cztowieka przejawia się w stowie $e^{24}$. Cechą stworzenia duchowego - obrazu Boga - jest to, że nie tylko istnieje dzięki Bogu, ale również Go poznaje. Bycie obrazem Boga i pozostawanie w bezpośredniej relacji poznawczej do Boga są jednym i tym samym. Innymi słowy, nauka o iluminacji i nauka o stworzeniu na obraz Boży są dla Filareta tożsame. To jednak odpowiada dokładnie stanowisku Augustyna ${ }^{25}$.

Dla poznawczej relacji pomiędzy Bogiem a człowiekiem istotne jest pojęcie oświecenia. Światło nadprzyrodzone stanowi specjalne oświecenie i specjalne poznanie obok zwykłego przyrodzonego poznania i ponad nim. Niedojrzaty umyst postrzega rzeczy bardziej zmystowo, empirycznie, po większej części bez zwiazku i porządku w pojęciach, a umyst wyksztatcony widzi mniej zmystowo, bardziej zgtębia się w rzeczy i odkrywa między nimi zwiazki i porządek; częścia za sprawa pośredniczacego między umystem i rzeczami światta, które może być przyrodzone lub nadprzyrodzone bądź wtaściwe światu, w którym żyjemy, zmieszane $z$ tego co, zmystowe i duchowe, lub czysto duchowe, a nawet Boskie... [...] Temu, kto chce widzieć przedmioty duchowe, nie wystarczy bez watpienia otworzyćcielesnych oczu i zapalićświecznik cielesnego światta. Im bardziej podnioste sa postrzegane rzeczy, tym bardziej podniosty powinien byćstan oka i światto, które pośredniczy w widzeniu. Co za tym idzie, dla ogladania rzeczy Boskich potrzebne jest Boskie światto $i$ dostosowany do niego stan umystu. W Twoim świetle, Panie, ujrzymy światto ${ }^{26}$.

W wewnętrznym oświeceniu istnieje w teologii Filareta różnica między naturalnym światłem a światłem płynącym z łaski. Nadprzyrodzone światło oznacza przede wszystkim działanie samego Boga. Łaska nie oznacza w istocie niczego innego, niż to, że Bóg staje się dla człowieka światłem, które oświeca go tak, jak słońce oświeca nasze cielesne życie, sprawiając, że jest ono w ogóle możliwe. Z tego ujęcia łaski jako Bożego światła wynika jej nieodłączność od dającego łaskę Boga, źródła światła łaski, tak że łaski nie można pojmować jako samodzielnej warstwy duszy, pochodzi ona bowiem zawsze z istnienia „ciągłości” między Bogiem i człowiekiem ${ }^{27}$. Augustiańska teza, że w dziedzinie duchowej „światło" ma sens rzeczywisty, a nie tylko obrazowy, zyskuje tu całkiem konkretną treśćc ${ }^{8}$. Jak cztowiek poznawat i poznaje Boga, czyni i czynit dobro do [czasu] chrześcijaństwa i bez chrześcijaństwa? Moja odpowiedź jest jedna: jeśli poznawat Boga, to poznawat pozostatościami pierwotnego światta w rozumie, przy pomocy pobożnej

24 Филарет (Ароздов), Творения. Wyrażając to w kategoriach nauki o świetle, możemy powiedzieć: bytowe odzwierciedlanie światła Bożego w człowieku jest założeniem i jedyną podstawą tego, że jest on również zwierciadłem poznawczym. Por. J. Ratzinger, Rozumienie objawienia..., s. 648.

25 Por. tamże, s. 649.

26 Фикарет (Ароздов), Творения.

27 Stąd przywrócenie podobieństwa obrazowi trzeba raczej rozumieć w sensie upodobniania, czynienia podobnym, upodobniania człowieka do Boga. To uczynienie obrazu wyraźniejszym w podobieństwie. Jeśli podobieństwo jest upodobnianiem, czynieniem podobnym, to musi istnieć ktoś, kto to sprawia. Sprawcą podobieństwa jest sam Bóg. Por. J. Ratzinger, Rozumienie objawienia..., s. 291-293. Prawdziwe „podobieństwo" do Boga polega na tym, żeby przejawiać sobą Jego i dokonywać działań właściwych Jemu. Por. И. Мейендорф, Жизнь и трудь Григория Паламь. Введение в изучение, Москва 1993, s. 237. O teologii światła por. tamże, s. 228, 237, 238-239.

28 Por. J. Ratzinger, Rozumienie objawienia..., s. 644. 
tradycji, jeżeli czynit coś w pewnym sensie dobrego, to dzięki pozostatościom pierwotnego dobra w woli. Po upadku cztowieka w grzech obraz Boży zostat w nim rozbity, ale niecatkowicie unicestwiony i zniszczony; wieczne Stońce zaszto w jego duszy, ale kilka promieni Jego światta jeszcze dotyka jej wyżyn ${ }^{29}$. Można więc powiedzieć, że nawet w stanie upadku świeci płomień utraconego raju i na chwilę przezwycięża ciemności wygnania, w których zamknęła nas nędza grzechu ${ }^{30}$.

\section{Rozum samowładczy}

Doskonałość człowieka, według Filareta, polega na jego zdolności poznawania świata i siebie. W nawiązaniu do tradycji augustiańskiej umysł opisywany jest jako partycypacja w świetle Bożego Ducha. Nie chodzi o podważanie poznania naturalnego, lecz o uznanie, że nauka nie jest jedyną formą aktywności ludzkiego ducha. Filaret, podążając za Augustynem, uważa, że nauka ma do czynienia z mundus sensibilis, który dzięki ars staje się dostępny i można się nim posługiwać. Ars pozwala na praktyczne korzystanie ze świata, ale ogranicza się do pozoru, jaki stanowią zjawiska zmysłowe w odróżnieniu od bytu, nieujawniającego się i nieprzybierającego form dostępnych zmysłom. Dla Filareta na drodze poznania istnieje możliwość wychodzenia ze świata widzialnego ku niewidzialnemu i wykraczania poza zjawiska widzialne ku rzeczywistości poznawalnej rozumowo, którą człowiek może ująć i poznać.

Filaret zwraca się przeciw „synergistycznemu wyobrażeniu” związku opartego na rozumowym poznaniu Boga i poznaniu udzielonym przez samego Boga. Absolutu nie można poznać z zewnątrz, lecz tylko przez Niego samego. Tylko tam, gdzie jest światło, człowiek może ujrzeć światło właściwe ${ }^{31}$. Trzeba zwrócić uwagę na istotną różnicę między rozumem samowładczym a posłusznym Bogu („rozum słuchający”32). Dzieje współczesnej filozofii Filaret rozpatruje pod kątem zaniku nauki o oświeceniu. Coraz silniejsze podkreślenie własnej aktywności ludzkiego ducha prowadzi do stopniowej rezygnacji z Bożego oświecenia i praktycznie kończy się twierdzeniem, że ludzki duch oświeca samego siebie: człowiek dysponuje własną mocą oświecania ${ }^{33}$. Największe niebezpieczeństwo stwarza suwerenny naturalny rozum: swoje własne światło uważając za jedyne wieczne i prawdziwe $e^{34}$. Traktowanie w czasach nowożytnych naturalnego

29 Można powiedzieć, że na wszystkich płaszczyznach poznania religijnego słowo i światło są pojęciami synonimicznymi. Jak podkreśla Ratzinger, u Augustyna zamiast o nauce o oświeceniu można by równie dobrze mówić o nauce o wezwaniu. Pojęciowemu polu „światło/oświecenie” odpowiada równie rozbudowane i rozwinięte pole pojęciowe „słowo/wezwanie”, które co do swej rozpiętości w dziele Augustyna może się mierzyć z nauką o świetle, a w dotychczasowych prezentacjach tego dzieła niesłusznie było pomijane. Augustyn nie chciał dostrzec różnicy między „światłem” i „słowem”, lecz łączył je znakiem równości. Por. tamże, s. 654.

Por. tamże, s. 325.

Por. tamże, s. 727.

Por. J. Schmidt, Teologia filozoficzna, przeł. P. Domański, Kęty 2006, s. 316.

Por. J. Ratzinger, Rozumienie objawienia..., s. 650.

Zdaniem Hansa Balthasara: A więc sam z siebie [rozum] na podstawie swego wtasnego światta dąży do 
światła rozumu tak, jakby było ono Bogiem, i budowanie na takim gruncie rozumienia fałszywej wolności prowadzi do najwyższej pychy. Ludzkość dąży do doskonatości! Nie jest to do końca nieprawdą. Filozofia znalazta tę myśl w religii, pozazdrościta jej wzniostości, porwata ja, ale nie zrozumiata i nie umiata jej użyć. Religia odkryta, że Bógprowadzi ludzkość do doskonatości i szczęścia, niepoprawne zto odcinając sprawiedliwym sadem, to, co można naprawić, naprawiając mitosierdziem, ofiarując swoją sitę stabości, ale nigdy nie ttumi sita wolności, a skłania ją do dobra miłością; dumna filozofia, źle podstuchawszy, zarozumiale opowiada, że ludzkość dąży do doskonatości sama z siebie, przezwyciężając (jak dodaje) przyrodę poprzez sztuke, odkrycia, wynalazki, lecz (co nie zawsze gtosi, ale pokazuje czynem) nie starając się zbliżyć do Stwórcy przyrody. [...] Uważa się, że można jednym spojrzeniem objać cata ludzkość, wskazuje się na jakiś tam autonomiczny jej postęp do doskonatości, chwali sie osiagnięcia tzw. oświecenia i wyksztatcenia, obiecuje się ztoty wiek, i tam, gdzie panuje najgtębsze przekonanie, że wszystko obecnie dokonuje sie i dokona samo z siebie, a najmniej dba się o btogostawieństwo i oświecenie z góry - tam wtaśnie nie ma ani cnoty, ani moralności, ani spokoju, ani bezpieczeństwa, wady sa tam nieokietznane, konflikty sięnie kończa, sojusze są niepewne, mądrośćstata się nie więcej niż przemystem, a wiedza towarem. [...] Powiedzcie, prosze, czy to rzeczywiście jest prosta droga i naturalny postęp ludzkości do doskonatości? Czy nie jest to wręcz przeciwnie znakiem rozstaju, manowców, otchtani, uników, btędu, upadku?35 Innymi słowy, jak ma decydować o prawdzie ten, kto jeszcze jej nie zna, kto ciągle ma jeszcze na nią zamknięte oczy i dlatego właśnie szuka kogoś drugiego, zdolnego doprowadzić do niejª ${ }^{36}$ W Kościele Bóg daje nam w widzialnych postaciach to, co niewidzialne, aż do momentu kiedy ostatecznie przyjdziemy do Niego. Powinnismy dązyć do wiecznej chwaty, nie do tego, co widzimy, ale do tego, co niewidzialne: to, co widzialne, jest doczesne, to, co niewidzialne wieczne. [...] Jeśli kiedykolwiek jako wyjątek od tej zasady jest dopuszczalne i należy z uwagapatrzećna to, co widzialne, to gtównie w tych przypadkach, gdy widzialne jest obrazem, tajemnym narzędziem, skarbnica tego, co niewidzialne, święte. [...] Takie sa widzialne obrazy, materia, znaki, obrzędy, sakramenty i liturgia. [...] Kościót Święty na wiele sposobów stara się przyblizać nas od widzialnego do niewidzialnego ${ }^{37}$.

\section{SPÓR O KOŚCIÓł}

Pod wpływem reform Piotra w Rosji następuje redukowanie religii do moralności, zmienia się również obraz Kościoła. Kościół przybrał kształt pedagogiczno-moralnej instytucji, którą można było podporządkować wyższym celom państwa (kościelność państwowa). W oświeconym absolutyzmie dominować zaczęła ta zewnętrzna koncepcja

odczytywania tajemnicy bytu bez promieniowania Bożej taski - H.U. von Balthasar, Metafizyka, cz. 2: Nowożytność, przel. L. Łysień, Kraków 2013, s. 55-56, Chwata. Estetyka Teologiczna, t. 3/1.

35 Фикарет (Ароздов), Творения.

36 Por. J. Ratzinger, Lud i Dom Boży..., s. 84.

37 Фикарет (Ароздов), Творения. 
Kościoła. Istota Kościoła nie wynikała już z jego struktury sakramentalnej, lecz miała być organizowana $\mathrm{w}$ duchu teorii społeczeństwa opartych na prawie naturalnym. Kościół był podporządkowany państwu jako stowarzyszenie zajmujące się szerzeniem ogólnoświatowego dobrobytu ${ }^{38}$. Zdaniem Gieorgija Florowskiego: $W$ swoim opiekuńczym dążeniu państwo policyjne w sposób nieunikniony zwraca sięprzeciw Kościotowi. Państwo nie tylko się nim opiekuje, ale też odbiera mu i bierze na siebie jego zadania. Bierze na siebie nieograniczona troskę o religijny i duchowy stan narodu. I jeżeli potem znów przekazuje albo powierza tę troskę duchowieństwu, to już tylko w ramach państwowej delegacji (vicario nomine) i tylko w granicach tej delegacji i polecenia zostaje wyznaczone miejsce Kościota wżyciu narodowo-państwowym, ale tylko na miarę pożyteczności i potrzeby pań$s t w a^{39}$. W czasach Piotra starano się stworzyć wrażenie, że prawosławie to tylko oryginalna, zrytualizowana odmiana protestantyzmu: prawostawie i protestantyzm sa tatwe do pogodzenia - facillime legitimeque uniantur, jak udowadniat petersburski akademik Koli, przyjaciel Prokopowicza, w ksiażce pod charakterystycznym tytutem: Ecclesia graeca lutheranisans (Lubeka 1723). Skutkiem tego Katarzyna II przekonywata, że nie ma prawie żadnej różnicy między prawostawiem i luteranizmem - le culte exterieure est tres different, mais l'Eglise s'y voit reduite par rapport a la brutalite du peuple... ${ }^{40}$

Odrodzenie zainteresowania istotą i rolą Kościoła w myśli rosyjskiej poszło w dwóch kierunkach. Pierwszy utożsamia się z postacią Filareta Moskiewskiego i centralne jest tu określenie Kościoła jako ciała Chrystusa, drugi - z myślą słowianofilów, w której znaczenia nabiera pojęcie ludu Bożego ${ }^{41}$. Żywe jest przekonanie, że renesans rosyjskiej teologii jest związany z myślą słowianofilów. Fiodor Stiepun w dziele Myśli o Rosji zauważył, że przeciwstawiając wczesnych słowianofilów Zachodowi, nie można zapominać, iż w pewnym sensie są oni nie mniej okcydentalistami niż ich przeciwnicy. Inteligencja podzielita się na dwa obozy w stosunku Rosji do Zachodu. Ten podziat i to pytanie zwiazane sq z innymi podziatami i innym pytaniem - z podziatem samego Zachodu na Zachód rewolucyjny $i$ antyrewolucyjny, z pytaniem, za jakim Zachodem pójdzie Rosja. [...] Jedyna różnica polega na tym, że dla stowianofilów prawdziwy Zachód - to Zachód chrzésijańskiego średniowiecza $i$ postrewolucyjnej filozofii tradycjonalizmu i romantyzmu; dla okcydentalistów prawdziwy Zachód - to Zachód już przezwyciężonego w romantyzmie oświeceniowego racjonalizmu i przysztej dominacji spoteczno-politycznej mas ludowych; opozycja stowianofilów i okcydentalistów krzyżuje się z opozycją Kościota i rewolucji, romantyzmu i oświecenia ${ }^{42}$. Przeciwieństwo religijno-całościowej i atomistyczno-racjonalnej świadomości u romantyków nie wychodziło poza granice Europy, konflikt ten do pewnego stopnia utożsamiał się z opozycją średniowiecze - nowożytność. Iwan Kiriejewski pozbawił to przeciwieństwo wewnątrzeuropejskiego charakteru, obwinił

\footnotetext{
38 Por. G.L. Müller, Dogmatyka..., s. 624.

39 Г. ФАоровский, Пути..., s. 54.

40 Tamże, s. 95.

${ }^{41}$ Więcej na ten temat por. D. Romanowski, Rosyjska myśl chrześcijańska. Filaret Moskiewski i Fiodor Dostojewski. Od teologii Kościota do metafizyki narodu, „Slavia Orientalis” 2017, vol. 66, nr 2, s. 225-251.

42 Ф. Степун, Сочинения, Москва 2000, s. 332; tłum. własne - D. R.
} 
całą Europę o serwilizm w stosunku do racjonalizmu i przeciwstawił jej Rosję, gdzie od początku, jego zdaniem, żywy był światopogląd religijno-całościowy ${ }^{43}$.

Słowianofilska idea „ludu niosącego Boga” sięga korzeniami niemieckiego romantyzmu z jego wyobrażeniem "ducha ludu” ${ }^{4}$. Jak zauważa Mikołaj Łosski, z takiego właśnie rozumienia harmonii jako soborowości lub wspólnotowości wynika negatywny stosunek Kiriejewskiego do przeceniania znaczenia hierarchii w Kościele. Mówiąc o pracy metropolity Makarego Prawostawnodogmaticzeskoje bogostowije, Kiriejewski zauważa: Wstęp do tej pracy zawiera pojęcia nie do pogodzenia z naszym Kościotem, na przyktad o nieomylności hierarchii, jak gdyby Duch Święty byt obecny w hierarchii oddzielnie od obecności w catym chrześcijaństwie ${ }^{45}$.

Chomiakow w pewnym sensie powtarza poglądy Andrieja Denisowa, współautora Odpowiedzi pomorskich powstałych w XVIII w., który podkreślał, że Kościół to nie ściany i dach, ale wiara i życie ${ }^{46}$. Dla Aleksieja Chomiakowa prawosławny lud jest stróżem wiary, ponieważ jest on „ludem niosącym Boga”: Duch Swięty dziata w nim i przemawia z gtębi jego wiary. Wybrana przez niego hierarchia ma za zadanie tylko poświadczyć wiarę, która jest w nim żywa ${ }^{47}$. Gwarantem tożsamości Kościoła nie jest już sakrament apostolskiej sukcesji; gwarancję Ducha stanowi lud w swej stałości i nieomylności. Jeśli Kościół można definiować, posługując się pojęciem ludu, to jego istotę najlepiej jest ujmować w perspektywie socjologicznej i politycznej. W konsekwencji „lud Boży” staje się wehikułem antyhierarchicznej i antysakralnej idei Kościoła, a nawet kategorią rewolucyjną, odpowiednią do tworzenia nowego Kościoła ${ }^{48}$. Jak podkreśla Joseph Ratzin-

43 Por. tenże, Чаемая Россия, Санкт-Петербург 1999, s. 346-347; D. Romanowski, Trzeci Rzym. Rozwój rosyjskiej idei imperialnej, Kraków 2013, s. 57-65.

44 Por. J. Ratzinger, O nauczaniu II Soboru Watykańskiego. Formutowanie, przekaz, interpretacja, przeł. E. Grzesiuk, Lublin 2016, s. 255, Opera Omnia, t. 7/2.

45 M. Łosski, Historia filozofii rosyjskiej, przeł. H. Paprocki, Kęty 2000, s. 25.

46 Zgodnie z koncepcją Andrieja i Siemiona Denisowych, autorów Odpowiedzi pomorskich, twórców renesansu myśli staroobrzędowej w XVIII w., Bóg złożył na barki Rosji historyczną misję obrony prawosławia i idei chrześcijańskiego narodu. W oczach staroobrzędowców car i patriarcha padli ofiarą herezji - najpierw reformy Nikona, a potem Piotra. W praktyce oznaczało to rezygnację z duchowego przywództwa i pierwszeństwa cara na rzecz całego chrześcijańskiego narodu. Akcent z cara - obrońcy wiary chrześcijańskiej - został przeniesiony na wszystkie rosyjskie miasta i wsie, na cały rosyjski chrześcijański naród. Była to radykalna zmiana w teorii chrześcijańskiego państwa, po raz pierwszy zostało zanegowane duchowe przywództwo monarchy, po raz pierwszy została podkreślona rola nie chrześcijańskiego państwa, a chrześcijańskiego narodu, po raz pierwszy zasada chrześcijańskiej soborowości zaczęła dominować nad zasadą hierarchii. Por. D. Romanowski, Trzeci Rzym..., s. 66.

47 Por. П. Фморенский, Около Хомякова, „Символ” 1986, nr 16, s. 141-227.

48 Por. J. Ratzinger, O nauczaniu II Soboru Watykańskiego..., s. 251. Jak podkreśla Joseph Ratzinger: $W$ przeciwieństwie do tych teologów, którym zabrakto tego wezwania - twierdzę, że przyjęcie koncepcji Kościota jako „Ludu Bożego” niesie raczej ryzyko cofnięcia się, niż możliwość pójścia naprzód, bowiem kryje się w nim niebezpieczeństwo odrzucenia Nowego Testamentu, akceptacja tylko Starego. "Lud Boży” to w rzeczywistości, wedtug Pisma Świętego - Izrael zjednoczony z Bogiem modlitwa o dochowanie wierności. Definicja Kościota ograniczona wytącznie do tego określenia oznacza porzucenie koncepcji Kościota zawartej $w$ Nowym Testamencie, gdzie określenia „Lud Boży" używa się wytacznie po to, by odwotując sie do starotestamentowego elementu Kościota, podkreślić Jego ciagty charakter, a tym samym zwiazek z Izraelem. Nowotestamentowa koncepcja Kościota polega na przyjęciu idei „Ciata Chrystusa”. W takim ujęciu 
ger: Wiara nie jest wedtug niego [Chomiakowa] sita umożliwiajaca uznanie objawionej nauki, lecz sita poznawcza, która jest bardziej realna i wznioślejsza niż myślenie wytacznie pojęciowe. Wedtug niego tę sitę wiary należy przypisywać nie jednostce, lecz wspólnocie prawowiernego ludu. Wynika stąd wedtug niego wymóg absolutnego poddania jednostki pod wtadze catości - także w wymiarze politycznym ${ }^{49}$.

Nowe odkrycie idei państwa i historii przez Hegla, a nadto powszechne myślenie organologiczne tego okresu w ogóle doprowadziły w epoce romantyzmu do ponownego odkrycia idei corpus mysticum, na podstawie której rozwinięto corpus-eklezjologię, przeciwstawianą populus-eklezjologii ${ }^{50}$. Ujęcie Kościoła jako ciała Chrystusa pozwoliło metropolicie Filaretowi przezwyciężyć jednostronnie prawnicze i instytucjonalne rozumienie Kościoła. Dla Filareta rozstrzygającego znaczenia nie miała ani metafora socjologiczno-polityczna, ani porównanie z organizmem biologicznym posiadającym wiele członków: Jeśli Kościót powszechny jest Ciatem Chrystusa, Syna Bożego, to owo ciato, bez watpienia, jest zawsze czyste, zawsze zdrowe, niezniszczalne, poniewaz inne niż takie bytoby niegodne Syna Bożego ${ }^{51}$.

cztonkami Kościota stajemy się nie poprzez przynależność typu socjologicznego, ale przez wszczepienie się $w$ Ciato samego Pana. Natomiast widei Kościota jako „Ludu Bożego" kryje się sugestia eklezjologiczna, zwracająca nas $w$ stronę Starego Testamentu, być może sugestie polityczno-partyjne, kolektywistyczne tenże, $W$ rozmowie z czasem, cz. 1, Lublin 2017, s. 66, Opera Omnia, t. 13/1.

49 Por. tenże, O nauczaniu II Soboru Watykańskiego..., s. 255. Pomimo krytyki Hegla oddziaływanie jego myśli na słowianofilów jest bezsprzeczne. Jeszcze Kant zauważył, że tylko wolność moralna oznacza podporządkowanie się prawu, które człowiek jako istota racjonalna ustala dla samego siebie. A skoro to, co racjonalne, jest uniwersalne, to wolność pozytywna, według Hegla, oznacza utożsamienie się z celami stojącymi wyżej niż pragnienia konkretnego ludzkiego indywiduum. Osiąga się to przede wszystkim poprzez utożsamienie konkretnej ludzkiej woli z wolą powszechną. Moralność jest w istocie moralnością społeczną, wolność pozytywną osiąga się poprzez udział w większej organicznej całości. Tą większą całością - w której konkretne da się pogodzić z tym, co ogólne, gdzie „wola ogólna obca" staje się własną - w koncepcji słowianofilów jest Kościół. Por. П. Фцоренский, Около Хомякова, s. 141-227. Taka wola jest miłością. Miłość jest rdzeniem wolności, jest wolna i spontaniczna - uświadamia siebie jako wolną i uznając tylko siebie, nie uznaje żadnej zewnętrznej władzy jako zasady własnych działań. A osiągnięcie przez wolę swojej pełni w miłości samo w sobie jest najwyższym dobrem, które można określić jako zrealizowaną wolność, absolutny i ostateczny cel dla podmiotu (w miłości utwierdza się jedność w różnorodności). Pokorne podporządkowanie się Chrystusowi to rezygnacja człowieka z poprzedniego pojmowania siebie (życie dla siebie) i uzyskanie nowego pojmowania siebie (zmiana samego siebie) w Kościele (życie dla innego), którego warunkiem jest trwanie w łasce, to jest w Kościele. A więc tylko w Kościele odnajdujemy jedność w różnorodności. Jednostka uświadamia siebie jako część całości w ten sposób, iż jej podmiotowość nie zostaje unicestwiona, lecz spełniona. Kościół nie jest abstrakcyjnym powszechnikiem, który stoi ponad swymi elementami: Kościół istnieje w swoich członkach i poprzez nich. A jednocześnie jego członkowie dzięki uczestnictwu w jego życiu zostają wyniesieni ponad indywidualizm (egoizm). Kwestię tę można ująć również tak, że w Kościele samoświadomość wzniosła się na poziom powszechnej samoświadomości - innymi słowy, Kościól jest jednością organiczną.

Por. J. Ratzinger, Kościót - znak..., s. 189.

51 Филарет (Ароздов), Творения. Kościół bowiem nie wyczerpuje się w kolektywie wierzących, ale jako Ciato Chrystusa jest czymś o wiele większym niż suma jego członków. Jak podkreśla John Meyendorff, tę soteriologiczną realność św. Grzegorz Palamas wyraża w swojej mistycznej nauce o Ciele Chrystusa. Por. И. Мейендорф, Жизнь и труды..., s. 245, 251. 
Ostatnimi czasy badacze zwracają uwagę na szczególne znaczenie Świątyni (sanktuarium kultowego) w eklezjologii Filareta. W Nowym Testamencie słowa „dom Boży” nigdy nie są odnoszone do chrześcijańskiej budowli kultowej, lecz oznaczają albo starotestamentową świątynię, albo chrześcijańską wspólnotę ${ }^{52}$. Jezus zapowiedział zburzenie starej świątyni i tym samym koniec starego kultu i porządku zbawczego oraz ustanowienie w jego miejsce nowego, którego centrum miało stanowić Jego własne ciało wydane na śmierć krzyżową. On sam, Ten, który przeszedł przez Krzyż i Zmartwychwstanie, jest jedynym miejscem, w którym Bóg jest dostępny dla człowieka, jedynym rzeczywistym miejscem kultu na świecie. Syn staje się człowiekiem i w swoim ciele przynosi Bogu z powrotem całe czlowieczeństwo ${ }^{53}$. Jego cztowieczeństwo przepetnione jest i przepojone Boża sita, poprzez hipostatyczne, osobowe w Nim zjednoczenie natury Boskiej i ludzkiej; a ponieważ przyjęte przez niego i ubóstwione cztowieczeństwo jako cztowieczeństwo jest wspótistotne z catym rodem ludzkim - to on jest otwartym dla wszystkich ludzi niewyczerpanym źródtem Boskiej, dajacej taskę, życiodajnej, uzdrawiającej, zbawiennej sity ${ }^{54}$. Miejscem obecności Boga nie jest więc kamienna budowla, lecz żywa wspólnota tych, którzy zgromadzili się w imię Boże i na Wieczerzy Pańskiej budują jedność Ciała Chrystusa, nowej świątyni. Gdy wiemy, że żadna wroga moc nie może zwyciężýżzywego, duchowego Kościota, to jest nadzieja, że również kamienny kościót czy świątynia nie zostanie zbezczeszczona i splądrowana ${ }^{55}$.

\section{PODSUMOWANIE}

$\mathrm{Na}$ początku artykułu postawione zostało pytanie: czy konserwatywna reakcja na Oświecenie jest skierowana wyłącznie przeciwko rewolucyjnym konsekwencjom, które wynikają z „oświeceniowego ideału społecznego”, czy przeciw samej treści tego ideału. Szczególnie ważne znaczenie w krytycznym ustosunkowaniu się do „oświeceniowego ideału społecznego" odgrywa recepcja myśli Augustyna w rosyjskiej myśli teologicznej. Można powiedzieć, że renesans rosyjskiej filozofii religijnej jest niejako związany z odkryciem Augustyna przez rosyjskich myślicieli XIX w. Poglądy słowianofilów są szeroko znane i wyżej zostały omówione wyłącznie w kontekście myśli Filareta. Chomiakow punktem wyjścia czynił stanowisko Kanta i interpretował je w kierunku idealizmu, podkreślając twórczą wartość moralnej jednostki. Zwrot ku niemieckiemu idealizmowi w obronie chrześcijaństwa był całkowicie naturalny. Trudno było znaleźć lepszego

52 Por. J. Ratzinger, O nauczaniu II Soboru Watykańskiego..., s. 260.

53 Por. tenże, Jezus z Nazaretu. Studia o chrystologii, cz. 1, przeł. M. Górecka, W. Szymona, Lublin 2015, s. 544, Opera Omnia, t. 6/1.

54 Филарет (Ароздов), Творения. Pogaństwo i Stary Testament różnią się od siebie w sposób zasadniczy, bo jedno służy bożkom, a drugie - jednemu żywemu Bogu. Mają jednak coś wspólnego, gdyż liturgia obydwu sprawowana jest tylko w mundus sensibilis. Obydwa oddają cześć bóstwu przez pośrednictwo zewnętrznych, widzialnych budowli i przez zewnętrzne czyny człowieka; stąd religia obydwu znajduje definitywny wyraz bądź w licznych świątyniach, bądź w tylko jednej. Por. J. Ratzinger, Lud i Dom Boży..., s. 234.

55 Tamże. Żadna budowla kościelna nie ma obietnicy wieczności, żadna nie jest niezastąpiona, każda może nam zostać zabrana, gdy znikną uzasadniające ją siły - tenże, Teologia liturgii..., s. 433. 
sprzymierzeńca dla obrony idei bytu ludzkiego jako moralnego i wolnego, który jest zależny od Boga i dokonuje wyboru między dobrem i złem. Niemiecki idealizm był nie tylko odpowiednią filozofią, ale „ostatnim słowem” w filozofii i śmiało można było z jego pomocą bronić Kościół przed szerzącymi się wówczas w Rosji empiryzmem, materializmem i nihilizmem. Jednakże pewne braki niemieckiego idealizmu nie zostają przezwyciężone w myśli słowianofilów, co przyczynia się do tego, że z czasem obrońcy prawosławia sami potrzebują obrony.

Centralnym zagadnieniem poruszonym $\mathrm{w}$ artykule jest kwestia powiązania natury i łaski. Étienne Gilson zauważył: Można przyjąc za pewne historycznie weryfikowalne prawo, że istnieje konieczna wspótzależność między sposobem ujmowania stosunku państwa do Kościota, sposobem ujmowania stosunku filozofii do teologii i sposobem ujmowania stosunku natury do taski ${ }^{56}$. W perspektywie politycznej oznacza to, że niesłuszne jest przyjmowanie istnienia porządku „doczesnego" lub politycznego odciętego od porządku duchowego, to znaczy porządku, który wynikałby z samego rozumu. Tak jak nie można zakładać dwóch odrębnych celów - jednego czysto naturalnego i drugiego nadprzyrodzonego, tak ostatecznym celem życia społecznego nie są dobra doczesne, lecz najwyższe Dobro, sam Bóg. Stąd prawdziwa sprawiedliwość naturalna i pokój naturalny nie mogą wypełnić się bez odniesienia do Kościoła i działania łaski.

$\mathrm{Z}$ drugiej strony pozwala to na rozgraniczenie stref Kościoła i państwa, chroni przed pomieszaniem tych dwóch porządków. Zgodnie z przekonaniem chrześcijan w religii nie chodzi o zwyczaj (religia nie jest wytworem państwa, a więc także nie jest funkcją państwa), lecz o Prawdę, która stanowi wartość absolutną, a więc nie jest ustanawiana przez państwo, lecz sama tworzy sobie nową wspólnotę, obejmującą wszystkich żyjących prawdą Bożą. Prawdziwą istotą Kościoła jest uczestnictwo w ciele Pana i poprzez to bycie samemu ciałem ${ }^{57}$.

Przywrócenie sakramentalno-misteryjnego wymiaru Kościoła pozwala właściwie ustosunkować się do tzw. kościelności państwowej, nie popadając równocześnie w niebezpieczeństwo związane z socjologicznym sposobem postrzegania Kościoła jako societas perfecta. Kościół nie może utożsamić się z żadnym państwem, lecz jest siłą, która relatywizuje całą rzeczywistość immanentną, wskazując na jedynego absolutnego Boga i na jedynego pośrednika między Bogiem i ludźmi: Jezusa Chrystusa ${ }^{58}$. Filaret zbyt wyraźnie i nieustępliwie przypominat o kościelnej niezależności i wolności - zwraca uwage Fłorowski - przypominat o granicach pañstwa. Kościót nie może być w państwie i państwo nie powinno być w Kościele - „jedność $i$ harmonia” między nimi powinna się realizować w jedności twórczej realizacji przykazań Bożych ${ }^{59}$.

56 D. Sureau, Teologie polityczne XX wieku, przeł. M. Grądzka-Holvoote, „Christianitas” 2011, nr 45-46, s. 125.

57 Por. J. Ratzinger, Lud i Dom Boży..., s. 550; И. Мейендорф, Православие в современном мире, Азбука верьь, s. 248-250, [online] https://azbyka.ru/otechnik/Ioann_Mejendorf/pravoslavie-i-sovremennyj-mir/, 10 VI 2016.

59 Por. Г. ФАоровский, Вера и культура. Избранньце труды по богословию и философии, Санкт-Петербург 2002, s. 260-261. 


\section{BIBLIOGRAFIA}

Balthasar H.U. von, Duch Prawdy, przeł. J. Zychowicz, Kraków 2005, Teologika, t. 3.

Balthasar H.U. von, Metafizyka, cz. 2: Nowożytność, przeł. L. Łysień, Kraków 2013, Chwata. Estetyka Teologiczna, t. 3/1.

Balthasar H.U. von, Pisma filozoficzne, przeł. M. Urban, D. Jankowska, Kraków 2006, Pisma Wybrane, t. 1.

Balthasar H.U.von, Teodramatyka, t. 2: Osoby dramatu, cz. 2: Osoby w Chrystusie, przeł. W. Szymona, Kraków 2003.

Copleston F., Historia filozofii, t. 7: Od Fichtego do Nietzschego, przeł. J. Łoziński, Warszawa 1995.

Daujat J., Easka i my, przeł. Z. Kowalska, Warszawa 1967.

Gilbert P.P., Wprowadzenie do teologii średniowiecza, przeł. T. Górski, Kraków 1997.

Historia teologii, t. 4: Epoka nowożytna, red. G. Angelini, G. Colombo, M. Vergottin, przet. W. Szymona, Kraków 2008.

Kerr F., Katoliccy teolodzy XX wieku. Od neoscholastyki do mistyki oblubieńczej, przeł. A. Wojtasik, Kraków 2011.

Ladaria L.F., Wprowadzenie do antropologii teologicznej, przeł. A. Baron, Kraków 1997.

Łosski M., Historia filozofii rosyjskiej, przeł. H. Paprocki, Antyk, Kęty 2000.

Morales J., Wprowadzenie do teologii, przeł. P. Rak, Kraków 2002.

Müller G.L., Dogmatyka katolicka, przeł. W. Szymona, Kraków 2015.

Napiórkowski A., Teologie XX i XXI wieku, Kraków 2016.

O’Donnell J., Wprowadzenie do teologii dogmatycznej, przeł. J. Szczurek, Kraków 1997.

Ratzinger J., Jezus z Nazaretu. Studia o chrystologii, cz. 1, przeł. M. Górecka, W. Szymona, Lublin 2015, Opera Omnia, t. 6/1.

Ratzinger J., Kościót - znak wśród narodów. Pisma eklezjologiczne i ekumeniczne, cz. 1, przeł. W. Szymona, Lublin 2013, Opera Omnia, t. 8/1.

Ratzinger J., Lud i Dom Boży w nauce św. Augustyna o Kościele. Rozprawa doktorska oraz inne opracowania nauki Augustyna i teologii ojców Kościota, przeł. W. Szymona, Lublin 2014, Opera Omnia, t. 1.

Ratzinger J., O nauczaniu II Soboru Watykańskiego. Formutowanie, przekaz, interpretacja, przel. E. Grzesiuk, Lublin 2016, Opera Omnia, t. 7/2.

Ratzinger J., Rozumienie objawienia i teologia historii wedtug Bonawentury. Rozprawa habilitacyjna i studia nad Bonawentura, przeł. J. Merecki, Lublin 2014, Opera Omnia, t. 2.

Ratzinger J., Teologia liturgii. Sakramentalne podstawy życia chrześcijańskiego, przeł. W. Szymona, Lublin 2012, Opera Omnia, t. 11.

Ratzinger J., Wrozmowie z czasem, cz. 1-2, Lublin 2017, Opera Omnia, t. 13/1-13/2.

Ratzinger J., Zmartwychwstanie $i$ życie wieczne. Studia o eschatologii $i$ teologii nadziei, przeł. J. Kobienia, Lublin 2014, Opera Omnia, t. 10.

Romanowski D., Rosyjska myśl chrześcijańska. Filaret Moskiewski i Fiodor Dostojewski. Od teologii Kościota do metafizyki narodu, „Slavia Orientalis” 2017, vol. 66, nr 2.

Romanowski D., Trzeci Rzym. Rozwój rosyjskiej idei imperialnej, Kraków 2013. 
Romanowski D., Źródta rosyjskiej myśli konserwatywnej. Teologia polityczna Filareta Moskiewskiego, „Politeja” 2016, nr 45, [online] http://dx.doi.org/10.12797/Politeja.13.2016.45.03.

Schmidt J., Teologia filozoficzna, przeł. P. Domański, Kęty 2006.

Sokolowski R., Bóg wiary i rozumu. Podstawy chrześcijańskiej teologii, przeł. M. Romanek, Kraków 2015.

Sureau D., Teologie polityczne XX wieku, przeł. M. Grądzka-Holvoote, „Christianitas” 2011, nr 45-46.

Szwed A., Rozum wobec chrześcijańskiego Objawienia. Kant, Hegel, Kierkegaard, Kęty 2011.

Turner D., Tomasz z Akwinu. Portret, przeł. M. Romanek, Warszawa 2017.

Wagner H., Dogmatyka, przeł. J. Zychowicz, Kraków 2007.

Мосский В., По образу и подобию, Москва 1995, [online] http://www.predanie.ru.

Мейендорф И., Жизнь и труды Григория Паламы. Введение в изучение, Москва 1993.

Мейендорф И., Православие в современном мире, Азбука веры, [online] https://azbyka.ru/ otechnik/Ioann_Mejendorf/pravoslavie-i-sovremennyj-mir/.

Романовский А., Некоторые аспекты богословия славянофилов, „Филаретовский амьманах" 2012, nr 10.

Степун Ф., Сочинения, Москва 2000.

Степун Ф., Чаемая Россия, Санкт-Петербург 1999.

Тихомиров $\Lambda$., Государственность и религия, Электронная библиотека RoyalLib.com, [online] https://royallib.com/book/tihomirov_lev/gosudarstvennost_i_religiya.html.

Фикарет (Ароздов), Творения, [online] http://www.predanie.ru.

Фцоренский П., Около Хомлкова, „Символ” 1986, nr 16.

ФАоровский Г., Вера и культура. Избранньце труды по богословию и философии, Санкт-Петербург 2002.

ФАоровский Г., Пути русского богословия, [online] http://www.predanie.ru.

Хондзинский П., Святитель Филарет Московский. Богословский синтез эпохи. Историко-богословское исследование, Москва 2010.

Dr hab. Dymitr ROMANOWSKI - adiunkt w Katedrze Kultury Bizantyńsko-Prawosławnej w Instytucie Rosji i Europy Wschodniej na Wydziale Studiów Międzynarodowych i Politycznych Uniwersytetu Jagiellońskiego. Obszar zainteresowań: historia Kościoła, historia rosyjskiej kultury chrześcijańskiej, historia rosyjskiej myśli filozoficzno-religijnej, teologia i filozofia polityczna, chrześcijańska antropologia, wybrane aspekty międzykonfesjonalne i międzyetniczne ze szczególnym uwzględnieniem problematyki polityczno-społecznej przestrzeni postradzieckiej. 